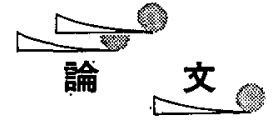 \\ 極超音速飛翔体周りの流線の放電を用いる 新しい可視化法*
}

西 尾 正 富**

\section{A New Visualizing Method of Streamlines Around Hypersonic Vehicles by Using Electrical Discharge}

\author{
Masatomi NiSHIO
}

\begin{abstract}
This paper describes a new visualizing method of streamlines around models in hypersonic flows by using an electrical discharge. First, the visualization of a streamline around a wedge is carried out. The result shows that the visualized streamline in the shock layer is approximately parallel to the wedge surface. The theoretical streamline is considered to be parallel to the wedge surface. From this, it is proved that the new method is available for the visualization of streamlines around hypersonic vehicles. Moreover, the visualization of a streamline around a more complicated model shape is carried out, successfully.
\end{abstract}

\section{1. 緒言}

極超音速飛翔体周りの流れ場を解明する際に， その飛翔体周りに生じる 3 次元衝撃波形状，王力 分布, 流線形状などは重要な情報となる。これら の中で， 3 次元衝撃波形状の可視化法について は，最近，西尾”により，放電を用いる新しい可 視化法が提案されてきた。李た，飛翔体周りの圧 力分布测定法については, 西尾, 木村 ${ }^{21,31,41} に よ$ り，磁気テープを用いる方法が報告されてきた。

しかしながら，極超音速飛翔体周りに生じる流 線の可視化法については，重要な問題であるにも かかわらず，その有効な可視化法は筆者の知る限 り，今まであまり報告されていなかったよらであ る。その理由は, 極超音速流線の可視化は非常に
難しく，適当な可視化手法が開発されていなかっ たことによると思われる。極超音速流線の可視化 を困難にする主な理由は，実験室で得られる極超 音速流が通常，かなり希薄，高速から持続時間が 短いといら条件の場合が多いからであると考皇ら れる。流線の可視化に際して一般に用いられるト レーサ法は，流体が希薄な場合にはそのトレーサ 粒子が流体の流れに一致しなくなり，その使用が 困難になる。屯た，流体が非常に高速な場合に も，トレーサ粒子の慣性力が大きくなり，したが って流体の流れとのずれが大さくなる。さらに被 写体としてのトレーサの移動速度が大さくなり,

したがって光量が少なくなり写真観測が困難にな る。また，極超音速流の上らな高エンタルピーの 流体の持続時間を長くするためには多大な費用が かかるので，乙たがって通常の極超音速風洞の持 続時間は非常に短く，そしてそのような持続時間 
の短い流体の流線の可視化には，当然のことなが らいらいろな困難が伴う。

したがって，これらの䈣しい流線の可視化の条 件下に和いても，その可視化ができる手法の開発 が望をれていた。その方法として，筆者は放電を 利用する可視化法を開発したので，本論文におい てそのことについて述べる。

\section{2. 可視化原理}

極超音速飛翔体周りの流線の可視化法は次に述 ベる考えに基づいている。

可視化原理を説明するため，図１飞示すような くさび周りに生じる流線を考光る。初め衙撃波 を交差するように一対の電極間に高電生を加光て 火花放電を発生させる。そしてこの後も継続して 低い電圧を加兄，電流を流し続けることにより， 放電を持続させる。このとき放電路は気流に乗っ て移動する。そしてこのドリフトする放電路から

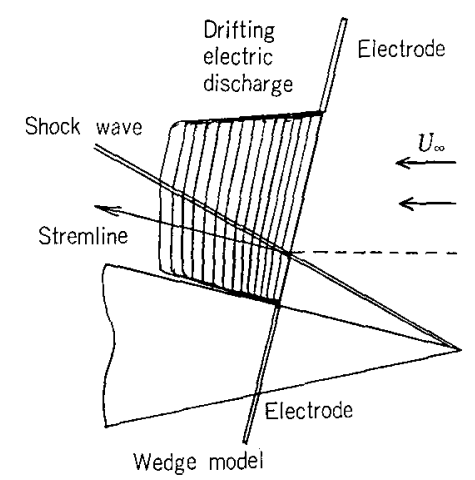

Fig. 1 Illustration of visualizing principle.

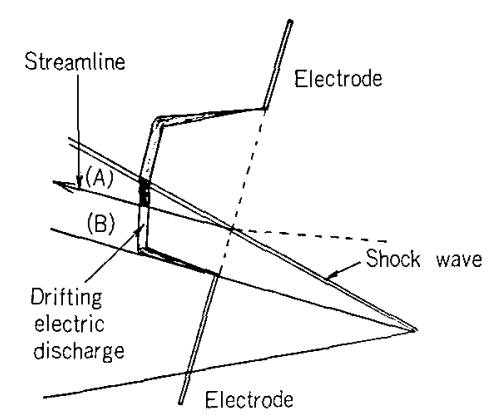

Fig. 2 Drifting electric discharge in the regions (A) and (B).
は発光が続く。しかしながらこのドリフトする 放電路からの発光は，この放電路全体にわたって 一定の強さで発光するわけではない。ドリフトす る放電路からの発光は, 初めの火花放電と衝撃波 が交差する点を通過する流線上で，その強さは変 化する。その様子の一例を図2に示す。この図 は, 初めの火花放電が発生してからある時間が経 過した時の放電路の例えを描いている。このよう に流線上で放電路の発光強さが急に変化するの は, その場所で，電子に上る分子の励起 関数 ${ }^{1} か ゙$ 急に变化するからである。そしてこの励起関数は 放電の発光強さに大きくかかわっている。励起関 数が急に変化するのは，その場所における電場の 変化が放電路中を㓌極から陽極见走行する電子の エネルギーを急に変えるからである。この場所で 電場が变化する理由は，図 2 に示す A 領域（衝撃 波と流線の間の領域）とB領域（流線とくさび表 面の領域）に扣いて，イオン濃度が異なるからで ある。これら $\mathrm{A} ， \mathrm{~B}$ の領域でイオン濃度が異なる 理由は二つ考光られる。その一つの理由は, 初め に高電仕で火花放電を発生させる時, イオンが発 生するが，一樣流中と衝撃波層の雨領域に打引る

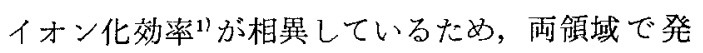
生するイオン濃度が異なることである。二つめの 理由は，そのイオンを含んだ一様流中の気流は衝 撃波を通過してA領域に入るが，その際の密度変 化に伴い一様流中から $\mathrm{A}$ 領域へのイオン濃度の变 化を伴ら。これら二つの理由により, 流線の位置 で急に放電の発光強さが变化する。したがって， このドリフトする放電路の写真を観測することに より流線が可視化できる。

\section{3. 実験装置と実験方法}

本実験に用いられた極超音速風洞の写真を図 3 に示す。この風洞の主な性能は、マッ八数が 10 , レイノルズ数が $2 \cdot 10^{6} / \mathrm{m}$, 一様流速が $10^{3} \mathrm{~m} / \mathrm{sec}$, 一様流密度が $4 \cdot 10^{-3} \mathrm{~kg} / \mathrm{m}^{3}$, そして気流の持続

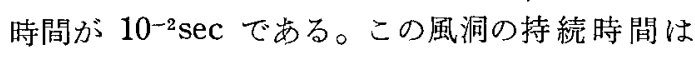
$10^{-2} \mathrm{sec}$ と短く，この間に流線の測定が成されな ければならない。このため図 4 亿示す放電回路を 試作し，これを用いて以下のような手順で測定が 行われている。風洞の銃身端付近に取り付けた圧 


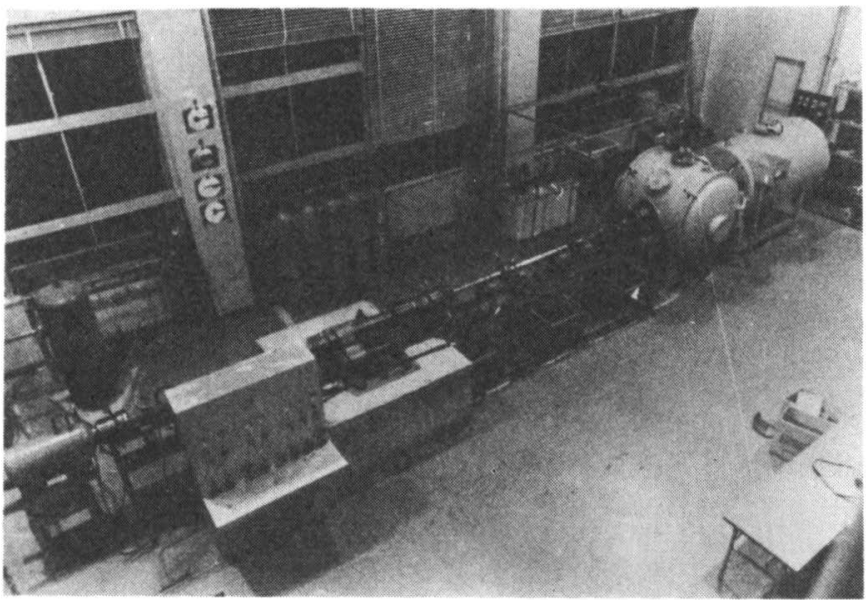

Fig. 3 Hypersonic tunnel.

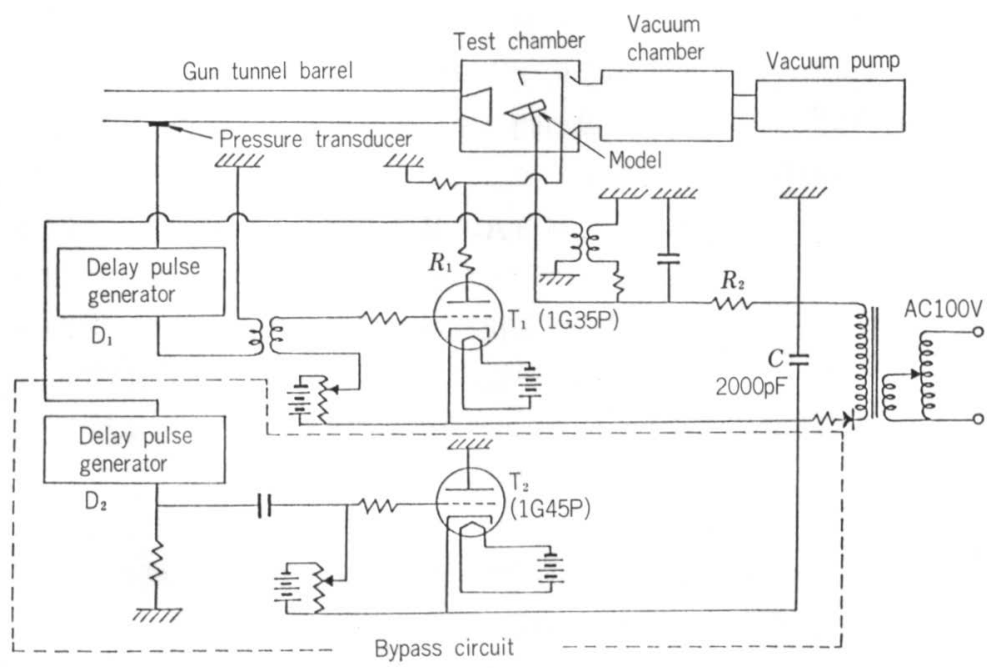

Fig. 4 Electric discharge circuit.

電素子（チタン酸バリウム）が銃身内のフリーピ ストン前方に生じる衝撃波を受けて信号を出す。 この信号は遅延パルス発生器 $\left(\mathrm{D}_{1}\right)$ の入力信号に なる。ここで一様流が得られるまで適度な時間遅 延がなされてからサイラトロン $\left(\mathrm{T}_{1}\right)$ の作動入力 になる。このときサイラトロンが働き放電回路が 閉じて，コンデンサー $(C)$. 亿蓄電されていた電 荷により放電電極間に高電圧が印加される。この 結果火花放電が自然発生する。発生した放電を流 線可視化に必要な時間継続させた後, バイパス回 路 $\mathrm{B}$ のサイラトロン $\left(\mathrm{T}_{2}\right)$ を働かせ，コンデンサ - $(C)$ に蓄えられている電荷をアース側に放出 させてこの放電を終わらせる。この間カメラを開 放状態にしてドリフトする放電路を写真観測す

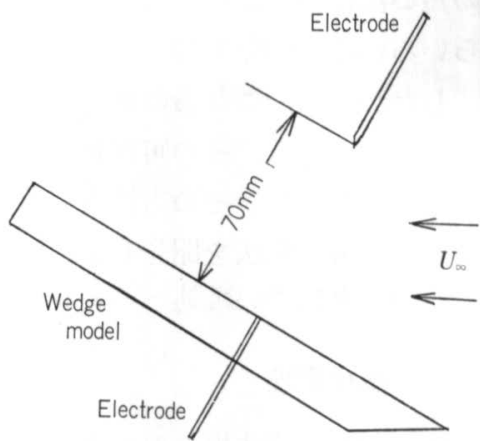

Fig. 5 Arrangement of model and a pair of electrodes.

る。

\section{4. 流線の可視化}

初めにくさび周りに生じる流 線の可視化を行い本方法による 可視化結果の妥当性を調べる。 くさび模型と電極の配置を図 5 に示している。電極は点一点電 極が用いられ, その両電極間の ギャップは約 $7 \mathrm{~cm}$ であり,こ のくさび模型の迎え角は $30^{\circ}$ に 設定している。ここでは陰極で ある点電極を一様流中に設定し ており，陽極である点電極をく さび模型の中に埋め込んでい る。この電極間に初期電圧 $2500 \mathrm{~V}$ を印加して放電を発生させ，この放電を 約 $100 \mu \mathrm{sec}$ 持続させる。本可視化法においては, 放電中に発生するイオンの量が可視化精度に大き く影響すると考兄られる。その理由は, 放電エネ ルギーが大きくなりすぎると衝撃波形状を乱すだ けでなく, 流線形状そのものも乱されてしまらか らである。このため実験を行うにあたっては, 電 極間に印加される初期印加電圧た゚けでなく, 放電 中に扔ける両電極間に印加される電圧值や電極間 に流れる電流值についても十分注意がはらわれて いる。そしてこの電圧值や電流値の調節には, 図 4 中に書き示している放電回路の抵抗 $R_{1}$ と $R_{2}$ を適当な值に設定して実験が行われている。回路 抵抗を十分小さくすると, 発生するイオンの量は 
きわめて少なく押さえられると考えら れ，したがって流れ場の衝撃波形状の 乱れや, 可視化対象の流線自体の乱れ もきわめて小さいものと考光られる。 しかしながら，あまりに回路の抵抗が 大き過ぎると放電からの発光が非常に 少なくなり, 高感度の>ィルムを用い ても, その放電から発する光りの観測 は困難となる。また, 火花放電の発生 が遅れて, 点一点電極間の所定の位置 に放電を発生させるのが困難になる。 したがってこのような可視化実験には 適度な回路抵抗值を選択する必要があ る。以上の考慮の下に可視化されたそ の結果の一例を図 6 亿示す。可視化さ れた流線形状はくさび表面にほぼ平行 であることを示している。一方，〈さ び周りの理論的流線は, くさびに平行 であることが知られている。このこと から，可視化結果は妥当なものである と考学られる。したがって, 放電によ る本可視化法は極超音速流線の可視化 に適用可能であると判断できる。

続いてさらに複雑な模型形状周りに 生じる流線の可視化を試みる。使用さ れた模型形状と電極の配置を図 7 亿示 す。この図に示すよらに模型は平板の 先端にくさびが取り付けてある。この ような模型の形状は極超音速飛翔体と してはきわめて基本的な形状ではある が, このような基本形状の模型周りに

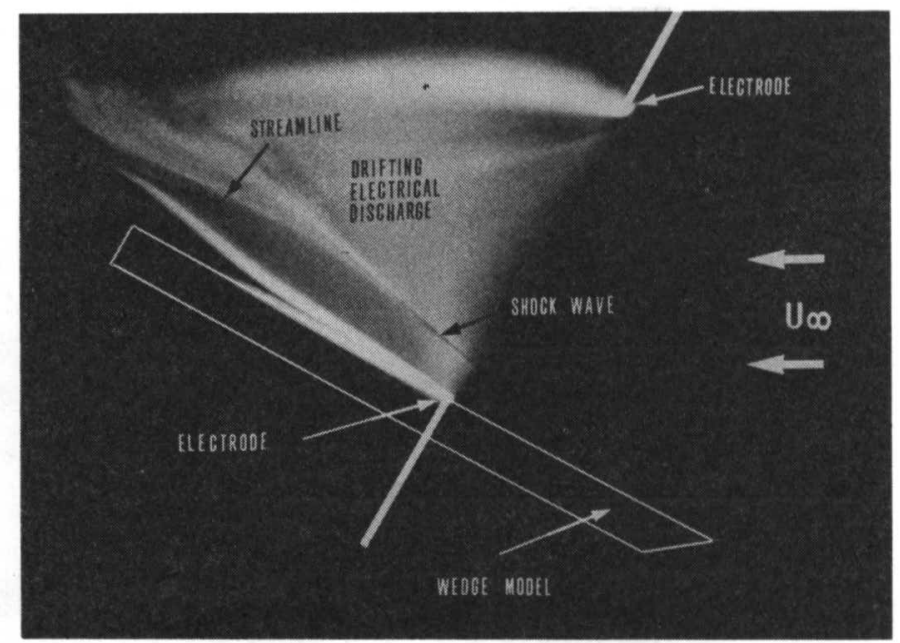

Fig. 6 Visualized streamline around hypersonic wedge.

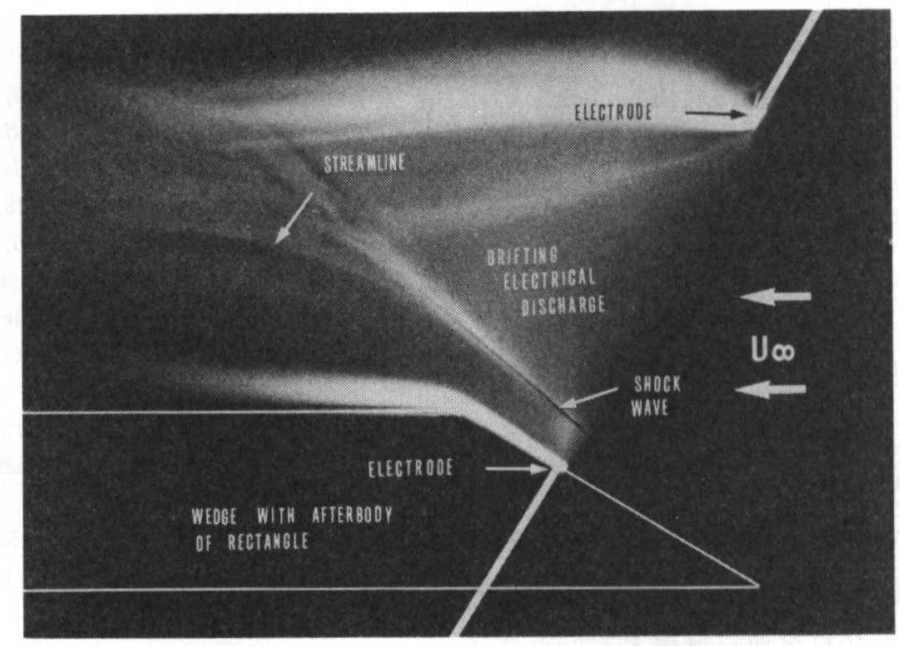

Fig. 8 Visualized streamline around hypersonic wedge with afterbody.

生じる流線すら, 筆者の知るかぎり, その有効な 可視化法が確立されていなかったので, 今までに その可視化例は報告されていなかった。ここでは くさび模型は先ほどの実験と同様その傾き角を $30^{\circ}$ にしている。そしてそのくさびの後に取り付 けられた平板は流れに平行に設定している。この ような模型形状では, 図中に示す B点から膨張波 が生じ, そのために流れはそのB点付近で曲げら れる。このような模型に対して先ほどの実験条件 と同様にして可視化した結果を図 8 に示す。図に は, 膨張により流れが曲げられている様子がはっ きりと示されている。ここで可視化された流線が 妥当なものであるかを調べるために同じ模型に生

Fig. 7 Arrangement of medel and electrodes. 
- - - - Experimental streamline Theoretical streamline

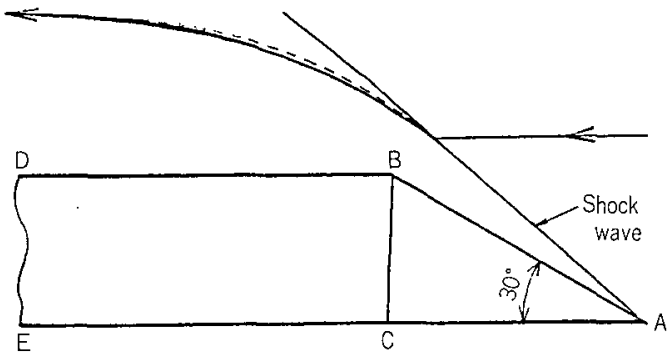

Fig. 9 Experimental and theoretical streamlines.

じる流線形状を特性曲線法を用いて計算し，その 計算結果を図 9 に載せる。そして比較のために, 可視化された流線形状を読及取った結果を同じ図 9 に合わせ載せる。図 9 によると，可視化された 結果は特性曲線法により求められた計算結果とほ とんどー致したものであることが分かる。したが って本流線可視化法はこのような複雑な模型形状 に対してもその流線形状の可視化が可能であると 判断できる。

\section{5. 結 論}

本論文では極超音速飛翔体周りの流線の可視化 法について述べた。その可視化原理は, 衝揧波を 交差するように火花放電を発生させ，さらにこの 放電を持続させると，衝撃波と初めの火花放電と の交点を通る流線上で，ドリフトする放電の発光
強さが，他の部分と異なるという考鼻に基づい た。このドリフトする放電を写真観測することに より，流線の可視化ができる。初めに極超音速流 中に置かれたくさび周りに生じる流線を可視化 し，その可視化結果が妥当なものであることが示 された。さらに複雑な形状の模型周りに生じる流 線の可視化を成功裹に行った。これらの結果か ら，放電を用いる本可視化法は極超音速飛翔体周 りの流線の可視化に対して有効な方法であると判 断できた。

\section{謝 辞}

本研究を遂行するに当たり, 神戸大学工学部の 極超音速風洞を使用いたしました。このことにつ き関係者の方々に謝意を表します。

\section{参考文献}

1) Nishio, M.: New Method for Visualizing Three-Dimensional Shock Shapes Around Hypersonic Vehicles Using an Electrical Discharge, AIAA Journal, Vol. 28, No. 12, (1990) pp. 2085-2091.

2) Nishio, M. and Kimura, T.: Measuring Method of Pressure Distribution on Surface of Hypersonic Vehicles by Using Magnetic Tape, Memoirs of Faculty of Engineering, Kobe University, Japan. (1986) pp. 63-71.

3) Kimura, T. and Nishio, M.: New Method for Measurement of Surface Pressure Using Magnetic Tape, AIAA Journal, Vol. 27, No. 11, (1989) pp. 1579-1583.

4）西尾，木村：磁気テープを用いる新しい表面圧切分布測定 法，日本機树学会論文集（B編）56巻，532号，（1990） pp. $3799-3804$. 


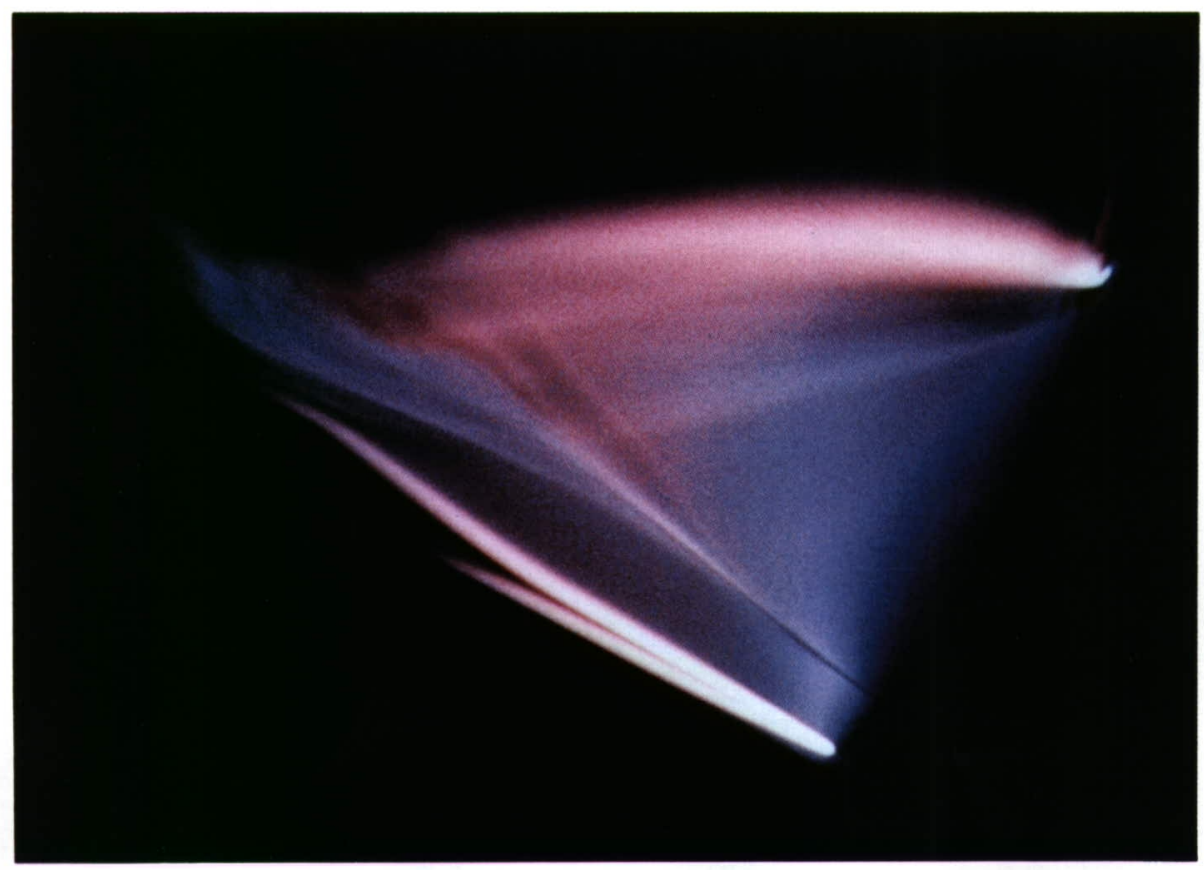

口絵 1 Visualized streamline around hypersonic wedge.(本交228頁参照)

(福山大学 西尾正富)

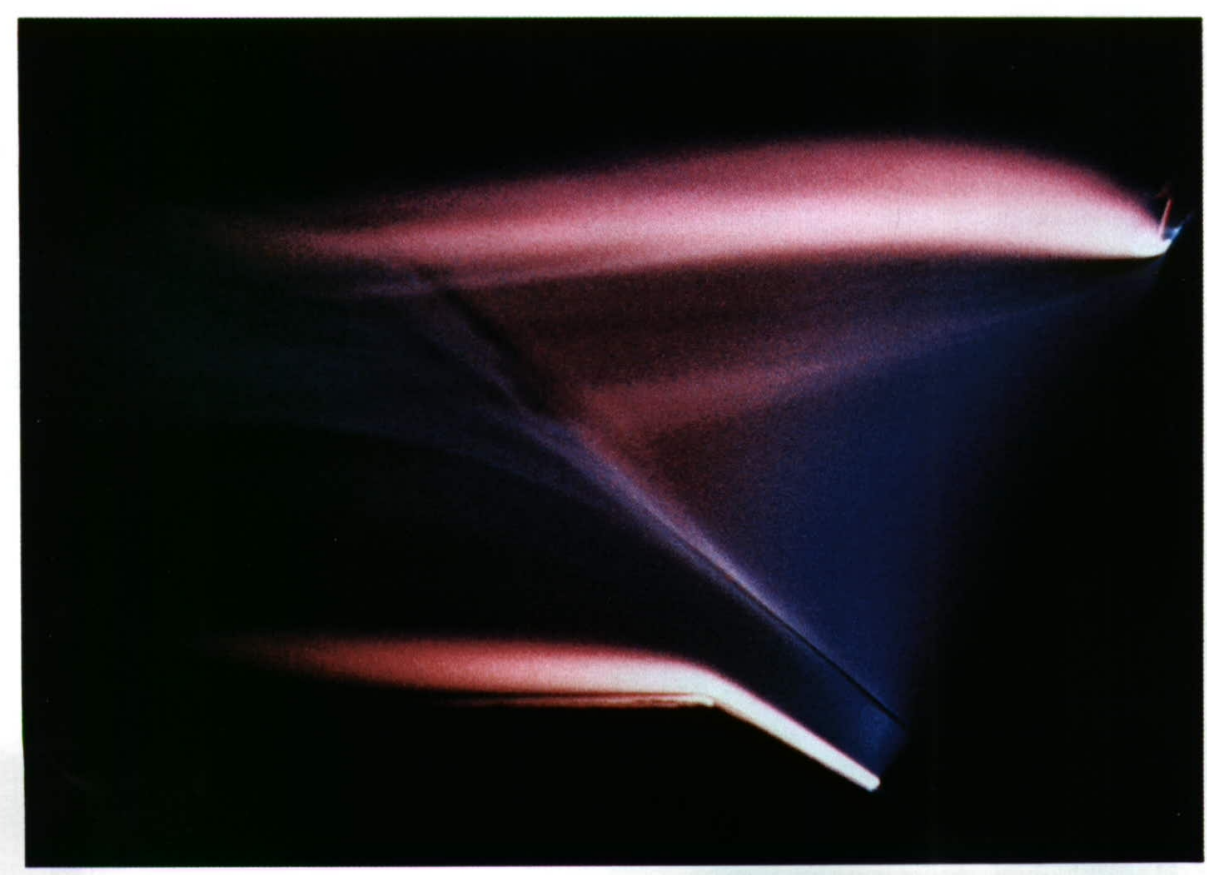

口絵 2 Visualized streamline around hypersonic wedge with afterbody.(本交228頁参照) (福山大学 西尾正富) 